\title{
Unutulmaz Turizm Deneyimi ve Tekrar Ziyaret Etme Niyeti Arasındaki ilişki*
}

The Relationship Between Memorable Tourism Experience and Revisit Intention

\author{
Onur Cüneyt KAHRAMAN**, Haluk TANRIVERDi*** \\ ** (Sorumlu Yazar) Dr. Öğr. Üyesi, Bolu Abant İzzet Baysal Üniversitesi, Turizm Fakültesi, Turizm İşletmeciliği Bölümü, Gölköy Yerleşkesi, 14030, Merkez, Bolu. \\ E-posta: onurcuneytkahraman@ibu.edu.tr \\ ORCID: 0000-0001-7773-8757 \\ *** Prof. Dr., İstanbul Üniversitesi, Turizm Fakültesi, Turizm İşletmeciliği Bölümü, Ek-Bina 2, 34134, Beyazıt, Fatih, İstanbul. \\ E-posta: haluk.tanriverdi@istanbul.edu.tr \\ ORCID: 0000-0002-2716-0405
}

MAKALE BILGILERI

Makale işlem bilgileri:

Gönderilme tarihi:31 Aralık 2020

Düzeltme: 3 Mart 2021

Düzeltme:18 Nisan 2021

Kabul: 19 Nisan 2021

Anahtar sözcükler: Unutulmaz

turizm deneyimi, Tekrar ziyaret etme

niyeti, Turizm türleri, Bolu.

\section{ARTICLE INFO}

Article history:

Submitted: 31 December 2020

Resubmitted: 3 March 2021

Resubmitted: 18 April 2021

Accepted: 19 April 2021

Key words: Memorable tourism experience, Revisit intention, Tourism types, Bolu.

\section{$\ddot{O Z Z}$}

Bu araştırmanın amacı, unutulmaz turizm deneyimi altında yer alan boyutların turistlerin tekrar ziyaret etme niyetine etkisinin incelenmesi ve turizm türlerine katılan turistlerin deneyimleri arasında bir farklılık olup olmadığının araștırılmasıdır. Bu kapsamda, nicel araștırma tekniklerinden anket kullanıımış ve unutulmaz turizm deneyimi ve tekrar ziyaret etme niyeti ölçekleri veri toplama aracı olarak kullanılmıştır. Bu ölçekler aracılığıyla, unutulmaz turizm deneyimi boyutları ve tekrar ziyaret etme niyeti arasında bağlantı kuran kavramsal bir model önerilerek test edilmiștir. Bolu ilini ziyaret eden turistlerden kolayda örneklem yöntemi kullanılarak 420 geçerli anket toplanmıștır. Gerçekleștirilen analiz sonucunda unutulmaz turizm deneyimi boyutları arasında yer alan yerel kültür ve yenilenme deneyimlerinin tekrar ziyaret etme niyetini olumlu olarak etkilediği sonucuna ulașılmıștır. Ayrıca, kültür turizmi, yayla turizmi, termal turizm ve kamp ve karavan turizmine katılan turistlerin unutulmaz turizm deneyimi boyutlarında yer alan yenilik, yerel kültür ve yenilenme boyutlarına göre farklılıklar içerdiği saptanmıştır.

\begin{abstract}
The principal objective of this study was to examine the effect of memorable tourism experience factors on the revisit intention of tourists and whether there is a difference between the experiences of tourists participating in tourism types. A quantitative method questionnaire was used, and memorable tourism experience and revisit intention scales were utilized. The present study proposes and tests a conceptual model establishing linkages between dimensions of memorable tourism experience and revisit intention. A total of 420 valid questionnaires were collected from the tourists visiting Bolu. The findings indicated that there was a significant and positive effect of local culture, and refreshment dimensions on revisit intention. Also, the research presented here confirms that the tourists participating in cultural tourism, plateau tourism, thermal tourism and camping and caravan tourism have differences between the novelty, local culture and refreshment dimensions.
\end{abstract}

\section{Giriş}

Deneyim kavramı, bireylerin öznel çıkarımlarını ifade eden ve gündelik yaşamlarından farklı alanlarda gerçekleşen faaliyetleri kapsamaktadır (Otto ve Ritchie 1996). İşletmeler, kendi pa-

\footnotetext{
* Bu çalışma, İstanbul Üniversitesi Sosyal Bilimler Enstitüsü Turizm İşletmeciliği Dalında, Prof. Dr. Haluk Tanrıverdi danışmanlığında yazılan, “Turist Deneyimi ve Tekrar Ziyaret Etme Niyeti Arasındaki İlişkide Kişilik Özelliklerinin Aracı Rolü: Alternatif Turizm Türlerine Katılan Turistler Üzerine Bir Araştırma." başlıklı doktora tezinden üretilmiştir.
}

zarlama stratejilerini oluşturabilmek ve tüketici tercihleri ile satın alma davranışlarını anlayabilmek için tüketicilerin yaşadığı deneyimleri incelemektedir (Pine ve Gilmore 1999). Deneyimlerin diş çevreden ve durumlardan etkilendiği bilinmektedir. Bununla beraber her bir bireyin kendine özgü deneyimsel değere sahip olduğu ve katılım gösterilen turizm türüne göre yaşanılan unutulmaz turizm deneyiminin değişkenlik gösterebileceği belirtilmektedir (Petrick 2002; Moss- 
berg 2007; Walls vd. 2011). Turist deneyimi karmaşık bir yapıda olması nedeniyle, turistik ürün sunan işletmelerin bu karmaşık yapıya dikkat ederek tüketicilerin istek ve ihtiyaçlarına yönelik hizmetler sunması gerekmektedir. Bu nedenle, işletmeler eşsiz bir deneyim sunabilmek adına farklı arayışlar içerisinde olan tüketicilere yönelik, davranış analizlerinde bulunmak zorundadır (Pine ve Gilmore 1999).

Unutulmaz turizm deneyiminin memnuniyeti, tekrar ziyaret etme niyetini ve sadakati olumlu etkilediğine dair birçok çalışma bulunmaktadır (Kim 2010; Kim vd. 2012; Kim ve Ritchie 2014). Ayrıca, turizm deneyiminin, kişilik özellikleri, demografik özellikler ve algılanan turistik alanın imajı gibi birçok değişkenle ilişkisi olduğu da belirtilmektedir (Walls vd. 2011; Bujisic vd. 2015; Zhang vd. 2018). Ancak unutulmaz bir turizm deneyimi içerisinde yer alan boyutların tekrar ziyaret etme niyetine etkisini inceleyen çalışmaların sayısı sınırlıdır (Kim ve Ritchie 2014; Gohary vd. 2020). Unutulmaz turizm deneyiminde yer alan boyutların turistlerin tekrar ziyaret etme niyetine olan etkisinin incelenmesi turistlerin davranışlarını anlamada yardımcı olabileceği düşünülmektedir.

Turistler unutulmaz bir deneyim yaşayabilmek adına, tipik turizm türleri haricinde farklı deneyimler yaşayabileceği turizm türlerine katılmaktadır (Kim 2014). Bu noktada turistlerin, istek ve ihtiyaçlarının farklılaşması sonucunda, özel ilgi turizmine, macera turizmine ve farklı turizm türlerine yönelik ilgisi artış göstermektedir (Çetin ve Bilgihan 2016). Bu nedenle farklı turizm türlerine katılan bireylerin deneyim türlerinin farklılık gösterdiği düşünülmektedir. Ayrıca, doyum noktasına ulaşmış olan bir turistik alana ziyaretlerin sürekliliğini ve bu alanın tekrar ziyaret edilmesini sağlamak için unutulmaz bir turizm deneyimi oluşturmak oldukça önemlidir (Sato vd. 2018). Bunun yanında, belirli bir turistik alanın özelliklerini araştırmak ve o bölgeye gelen turistlerin deneyimleri ve davranışları hakkında detaylı bilgi edinmek turistik ürün pazarlaması ve yeni ürünler oluşturabilmek adına oldukça önemlidir (Chandralal ve Valenzuela 2013; Zhang vd. 2018). Bu sayede, turistlerin satın alma davranışlarını etkileyebilecek etkenler belirlenebilmekte ve bireylere unutulmaz bir deneyim yaşatabilecek hizmetleri sunmak daha kolay hale gelebilecektir. Turistik ürün üreten işletmelerin de potansiyel turistlerin deneyimleri ve davranışsal niyetleri hakkında bilgi sahibi olmasıyla birlikte, günümüz rekabetinde avantajlı konuma gelebileceği söylenebilir. Turizm türlerinin yoğun olduğu Bolu ilinde unutulmaz turizm deneyimi ve tekrar ziyaret etme niyeti ilişkisi hakkında bir çalışmaya rastlanmamıştır. Bu araştırmada da yerli turistlerin unutulmaz turizm deneyimleri, tekrar ziyaret etme niyetleri ve katıldıkları turizm türünün yaşadıkları deneyimde herhangi bir farklılık oluşturup oluşturmadığını incelenecektir ve bu sayede alanyazına, turizm işletmelerine ve turistik alan yönetimine katkı sağlayacağ1 düşünülmektedir.

\section{KURAMSAL ÇERÇEVE}

Turist deneyimi (Otto ve Ritchie 1996: 166); “katılımclar tarafından hissedilen öznel bir zihinsel durumu" ifade etmektedir. Diğer bir tanıma göre turist deneyimi (Quan ve Wang 2004: 298) "gündelik yaşamdan farklı şeyleri deneyimleme yolu" şeklinde tanımlanmaktadır. Turist deneyimin oluşabilmesi için farklı yerlerde, belirli bir zaman diliminde edilen ve birbirine bağlı hizmetlerin bir araya gelmesi gerekmektedir. Bir deneyimin oluşturulmasındaki amaç; işlevsel olması, ilgi çekici olması, merak uyandırması, etkili ve unutulmaz olmasıdır. Bu sebeple yaşanılan deneyimin unutulmaz bir özellikte olması oldukça önemlidir (Pine ve Gilmore 1999). Olumlu unutulmaz bir turist deneyimi (Kim vd. 2012: 13) “olay gerçekleştikten sonra olumlu bir şekilde hatırlanan ve tekrar istenen olaylar" olarak tanımlanmaktadir.

Turizm alanyazınına bakıldığında, turist deneyimi ile alakalı olarak birçok çalışmanın gerçekleştirildiği görülmektedir (Thung ve Ritchie 2011; Walls vd. 2011; Kim vd. 2012). Otto ve Ritchie (1999) deneyimi; haz, zihin rahatlığı, ilgilenim ve tanınırlık olarak dört boyutta incelemektedir. Diğer bir çalışmada, turist deneyiminin güdü boyutları; fiziksel, zihinsel ve sosyal dene- 
yim olarak üç alt boyutta ele alınmaktadır (Aho 2001). Mossberg'e (2007) göre turist deneyimi duygusal, fiziksel, düşünsel ve ruhsal boyutlardan oluşmaktadır. Zhang ve diğerlerinin (2008) otel işletmeleri üzerine yaptığ çalışmada deneyimi oluşturabilmek adına otel işletmelerinde aktivite, sosyal etkileşim ve fiziksel çevrenin olması gerektiği ve deneyiminde işlevsel, duygusal ve psiko-sosyal boyutlarının bulunması gerektiğinden bahsetmiştir. Cetin ve Bilgihan (2016) ise kültür turizmine yönelik olarak sosyal etkileşim, otantik unsurlar, hizmet, kültür/miras ve karş1laşılan zorluklar olmak üzere turist deneyiminin beş boyut içerdiğini belirtmektedir. Tung ve Ritchie (2011) deneyimin unutulmaz olabilmesi için ise etki, beklenti, sonuç ve hatırlama boyutlarının bulunması gerektiğini belirtmiştir. Kim vd. (2012) tarafından oluşturulan unutulmaz turizm deneyimi; hazcılık, yenilik, yerel kültür, yenilenme, anlamlılık, ilgilenim ve bilgi boyutlarından oluşmaktadır.

Kim vd. (2012) tarafından oluşturulan unutulmaz turizm deneyimi ölçeğinde yer alan boyutlar incelendiğinde, haz duygusunun heyecan ve hatırlama gibi duygular aracılığıyla oluşan bir boyut olduğu ve bu duyguların turist deneyimi açısından önemli olduğu söylenmektedir (Otto ve Ritchie 1996). Cohen (1972) ise turist deneyiminin bireysel zevk, tercih ve gezi organizasyonuna bağlı olarak oluşan yenilik ve aşinalık barındıran bir boyuta sahip olduğunu belirtmiştir. İlgilenim boyutunda ise turistler deneyime dâhil olurken sosyal etkileşimde bulunmakta ve bu sayede yerel halk hakkında (yaşam tarzı, davranış kodları ve yeme-içme kültürü gibi) bilgi sahibi olmaktadır (Kim ve Ritchie 2014). Diğer bir boyut olan yenilenme, bireylerin hafızasında olumlu etki birakmaktadır (Kim, 2010). Hayes ve Macleod (2006) ise eğlence deneyiminin macera ve çeşitli etkinliklere katılımını içerdiğini belirtmektedir. $\mathrm{Bu}$ faaliyetlere katılmanın da bireylerin hafızasında etki bıraktığı bilinmektedir (Pine ve Gilmore 1999). Tüm bunlarla birlikte entelektüel olarak gelişmenin unutulmaz bir deneyim yaşamak adına önemli bir boyut olduğu söylenebilir (Tung ve Ritchie 2011).

\section{Araştırmanın Modeli ve Hipotezleri}

Unutulmaz Turizm Deneyimi ve Tekrar Ziyaret Etme Niyeti İlişkisi

Bir turistik bölgeye olan sadakatin, güdü ve memnuniyet düzeyi ile ilişkisi olduğu bilinmektedir (Yoon ve Uysal 2005). Ancak güdü ve memnuniyet gibi değişkenlerin yanı sıra tekrar ziyaret etme niyetini etkileyen birçok değişkenin olduğu da belirtilmektedir (Chen ve Rahman 2018; Gohary vd. 2020). Örneğin, turistlerin yaptıkları gezi sırasında akıllarında kalan olumlu bir düşünce onların tekrar ziyaret etme niyetini olumlu etkilemektedir (Oh vd. 2007). Chen ve Rahman (2018) ise kültür turizmine katılan turistlerin yaşadığ 1 unutulmaz turizm deneyimlerinin tekrar ziyaret etme niyetini etkilediğini vurgulamaktadır. Ancak, unutulmaz turizm deneyimi boyutlarının tekrar ziyaret etme niyetine olan etkisinin incelendiği çalışmalar ise sınırlı sayıdadır. Gohary vd. (2020) İran'da bulunan bir eko-turizm alanında yaptığ 1 çalışmada, elde edilen deneyim sonucunda oluşan memnuniyet düzeyi, davranışsal niyeti olumlu etkilemektedir. Ayrıca unutulmaz turizm deneyimi boyutlarından olan, hazcılık, ilgilenim, bilgi, anlamlılık, yenilik ve yenilenme boyutları da tekrar ziyaret etmeyi olumlu etkilemektedir. Kim vd. (2010) unutulmaz turizm deneyimi boyutlarında yer alan hazcılık, ilgilenim ve yerel kültür boyutlarının tekrar ziyaret etme niyetini olumlu şekilde etkilediğini belirtmektedir. Buna benzer olarak, Kim ve Ritchie (2014) unutulmaz turizm boyutlarından hazcilık, yenilenme, yenilik, yerel kültür ve ilgilenim boyutlarının tekrar ziyaret etme niyetini olumlu etkilediğini ortaya koymuştur.

Unutulmaz bir turizm deneyimi turistlerin karar verme aşmasında önemli bir role sahiptir (Chandralal ve Valenzuela 2013). Unutulmaz bir turizm deneyimi sağlamak ve tekrar ziyaret etme niyetini oluşturmak bu bakımdan önemlidir. Akılda kalıcı bir deneyim oluşturmak tekrar ziyaret etme niyetini oluşturulabileceği birçok çalışmada belirtilmektedir (Kim vd. 2012; Kim ve Ritchie 2014; Chen ve Rahman 2018). Bu kapsamda, bu araştırma için oluşturulan model ve hipotezler aşağıdaki gibidir: 
H1: Hazcllik boyutu, tekrar ziyaret etme niyetini olumlu etkilemektedir.

$\mathrm{H}_{2}$ : Yenilik boyutu, tekrar ziyaret etme niyetini olumlu etkilemektedir.

$H_{3}$ : Yerel kültür, boyutu tekrar ziyaret etme niyetini olumlu etkilemektedir.

$H_{4}$ : Yenilenme, boyutu tekrar ziyaret etme niyetini olumlu etkilemektedir.

H5: Anlamlilik, boyutu tekrar ziyaret etme niyetini olumlu etkilemektedir.

H6: Ilgilenim boyutu, tekrar ziyaret etme niyetini olumlu etkilemektedir.

$\mathrm{H}_{7}$ : Bilgi boyutu, tekrar ziyaret etme niyetini olumlu etkilemektedir.

\section{Turizm Türleri ve Unutulmaz Turizm Deneyimi ilişsisi}

Benzersiz bir deneyim yaşamak isteyen turistlerin, yerel halk ile tanışabileceği, farklı şeyler öğrenebileceği ve standartlaşmış olan kitle turizminden farklı turizm türlerine katılım sağladığ 1 görülmektedir (Kim 2014). Ziyaret edilen bölgenin kendine has birtakım farklılıkları bulunmakta ve bu farklilıklar turistlere eşsiz bir deneyim sunmaktadır. Bu alanlarda sunulan hizmetlerin yanında yerel halk ile tanışma, yenilenme ve doğayı tanıma isteği bölgeye ziyaretçi akımını sağlamaktadır (Arslaner ve Erol 2017). Ayrıca, unutulmaz turizm deneyimi içerisinde yer alan

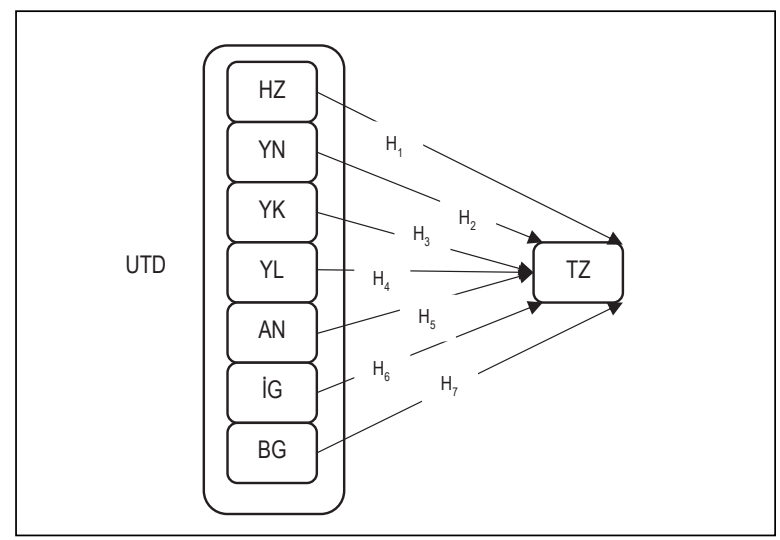

UTD: Unutulmaz Turizm Deneyimi, HZ: Haz, YN: Yenilik, YK: Yerel Kültür, YL: Yenilenme, AN: Anlamlılık, İG: İlgilenim, BG: Bilgi, TZ: Tekrar Ziyaret Etme Niyeti

Şekil 1. Araştırma Modeli ve Hipotezleri yenilik arayışının, karar verme aşamasında etkisinin olduğu ve bireylerin, kendi istek ve ihtiyaçlarına göre geliştirilen farklı turizm türlerinde katılarak, yeni deneyimler yaşamak istediği bilinmektedir (Petrick 2002). Bununla birlikte, bilgi edinmeye ve kendini geliştirmeye yönelik olarak deneyim yaşamak isteyenler açısından, deniz-kum-güneş harici olan turizm türlerinin büyük bir önemi bulunmaktadır. Tran ve Ralston (2006) macera turizmine yönelik olarak tatil yapmak isteyen bireylerin yeni deneyimler yaşamak ve benzersiz bir ortam içerisinde bulunmak gibi çeşitli güdülerinin bulunduğunu belirtmektedir. Walls ve diğerlerine (2011) göre, yiyecek içecek deneyimi ve kurvaziyer gemi turu deneyimi arasında belirli farklılıklar bulunmaktadır. Bu açıdan oluşturulan hipotez aşağıdadır:

H8: Turizm türleri ile unutulmaz turizm deneyimi arasında anlaml farklılık bulunmaktadır.

\section{YÖNTEM}

\section{Araştırmada Kullanılan Veri Toplama Araçları}

$\mathrm{Bu}$ araştırma kapsamında turistlerin unutulmaz turizm deneyimlerini ve tekrar ziyaret etme niyetlerini ölçebilmek için anket formu hazırlanmıştır. Bu kapsamda, hazırlanan anket iki bölümden oluşmaktadır. Birinci bölümde yaş, cinsiyet, medeni durum ve katılım sağlanan turizm türü gibi turistlerin demografik ve tanımlayıcı bilgilerini ölçen ifadelere yer verilmiştir. İkinci bölümde yedi boyut ve 24 ifadeden oluşan unutulmaz turizm deneyimi ölçeği (Kim vd. 2012) ve üç ifadeden oluşan tekrar ziyaret etme niyeti ölçeği (Kim vd. 2012) yer almaktadır. Unutulmaz turizm deneyimi ölçeği yedili Likert, tekrar ziyaret etme niyeti ölçeği ise beşli Likert ile ölçülmüştür. Unutulmaz turizm deneyimi ölçeğinin Türkiye örneklemi üzerinde uygunluğunu test edebilmek adına ölçek Türkçeye çevrilmiş ve alanında uzman üç akademisyenin görüşü alınmıştır. Kim vd. (2012) tarafından oluşturulan unutulmaz turizm deneyimi ölçeğinin diğer ölçeklere oranla turizm türlerine yönelik deneyimi daha iyi açıklayabileceği düşünülmüştür. Bu nedenle araştırma kapsamında bu ölçeğin kullanılması uygun görülmüştür. 


\section{Araştırma Alanı ve Örneklem}

Araştırmanın evrenini Bolu'da alternatif turizm türlerine katılım sağlayan turistler oluşturmaktadır. Bolu'nun araştırma alanı olarak seçilmesindeki neden, bu ilin turizm türleri bakımından büyük çekiciliklere sahip olmasıdır. Bolu ili sahip olduğu doğal ve kültürel güzellikler bakımından da oldukça zengin bir durumdadır. İklimi, tarihi varlıkları ve dört mevsim boyunca farklı turizm çeşitlerini sunması ve gelen turistlere ev sahipliği yapabilecek imkânlar oluşturması açısından Türkiye turizmine katkıda bulunduğu söylenebilir (Yosmanoğlu ve Engin 2003). Bununla birlikte coğrafi konumu itibariyle İstanbul ve Ankara gibi büyük illere yakın olması ve Batı Karadeniz bölgesinin başlangıcı konumunda olup Düzce, Bilecik, Eskişehir, Çankırı, Karabük, Zonguldak gibi illere komşuluk yapması nedeniyle bu illerden gelebilecek turistleri ă̆ırlayabilecek bir potansiyelinin bulunması nedeniyle araştırma alanı olarak seçilmiştir (Özcan 2005).

Bolu ilinde turizm faaliyetlerine katılan turistlerin toplam sayısı 568.053'tür ve bu turistlerin 490.614'ü yerlidir (Kültür ve Turizm Bakanl1$\breve{g}_{1}$ 2020). Ancak turizm türlerine katılan turistlerin sayısı net şekilde bilinmemesi nedeniyle veri toplama yöntemi olarak olasılıklı olmayan örneklem yöntemlerinden biri olan kolayda örneklem metodu kullanılmıştır. Araştırma verisi, 2018 Ağustos ve Ekim, 2019 Şubat ve Mart tarihlerinde turistlerin en fazla ziyaret ettiği bölgelere (Yedigöller Milli Parkı, Abant Milli Parkı, Gölcük Milli Parkı, Termal turizm hizmeti veren oteller vb.) gidilerek toplanmıştır. Bu alanlara gelen turistler gözlemlenmiş ve araştırma verisine sadece bireysel olarak bölgeyi ziyaret eden yerli turistler dâhil edilmiştir. Araştırma kapsamında sadece bireysel olarak bölgeyi ziyaret eden yerli turistlerin dâhil edilmesindeki neden bireysel olarak turizme katılan kişilerin gruplar halinde seyahat eden bireylere göre standart bir deneyim beklentisi içerisinde olmamaları ve kitle turisti olarak görülmemeleridir (Cohen 1972). Araştırma kapsamında toplam 478 kişiye anket uygulanmış, fakat bu anketler içerisinde analize uygun olmayan 58 anket değerlendirmeden çıkartılmıştır. Örnek- lem yeterliliği incelendiğinde 420 anketin analiz için uygun olduğu görülmüştür (Hair vd. 2014).

\section{Veri Analizi}

Araştırma kapsamında oluşturulan ilk yedi hipotezi test edebilmek adına, kısmi en küçük kareler yapısal eşitlik modellemesi (PLS-SEM) kullanılmıştır. Yapısal eşitlik modellemesi (PLSSEM), ölçüm modeli ve yapısal model olarak iki aşamadan oluşmaktadır (Anderson ve Gerbing 1988). Ölçüm modeli ve yapısal modeli oluşturabilmek adına PLS-SEM yöntemi kullanılmıştır. Bu yöntem birçok çalışmada kullanılmakta olup normal dağılım gerektirmeyen hem büyük hem de küçük örneklemlerin raporlanmasında kullanılabilmekte ve yapısal eşitlik modellemesini belirlemede önemli bir tutarlılık göstermektedir (Hair vd. 2017). Bununla beraber PLS-SEM yönteminin turizm araştırmalarında da sıklıkla kullanıldı̆̆1 görülmektedir (Do Valle ve Guy Assaker 2016; Usakli ve Kucukergin 2018). Bu nedenle verilerin analiz edilmesinde PLS-SEM kullanılmıştır. Araştırma verilerinin analizi sürecinde faktör yüklerinin ve yol katsayılarının anlaml1lıkları test edebilmek adına alanyazından önerildiği üzere 5000 örneklemli “bootstrapping” tekniği kullanılmıştır (Hair vd. 2017). Araştırmanın diğer bir hipotezini oluşturan turizm türleri ve unutulmaz turizm deneyimi boyutları arasındaki farklılığı ölçebilmek adına çoklu yanıtlar birleştirilerek tablo oluşturulmuş ve Bonferroni düzeltmesi kullanılarak gruplar arası karşılaştırma gerçekleştirilmiştir.

\section{BULGULAR}

Katılımcıların yaş, cinsiyet, medeni durum, eğitim durumu, gelir durumu ve mesleklerine yönelik bilgiler incelendiğinde, katılımcıların büyük çoğunluğu 18-24 yaş (yüzde 33,6) ve 25-34 yaş (yüzde 36,9) aralığında bulunmaktadır. Daha çok bekar (yüzde 54,8) olan katılımcıların cinsiyet dağılımına bakıldığında ise 212 Kadın ve 208 Erkek katılımcı bulunduğu görülmektedir. Katılımcıların büyük çoğunluğunun lisans derecesine (yüzde 47,6 ) sahip olduğu ve gelir düzeylerinde ise dengeli bir dağılım bulunduğu görülmektedir. 
Tablo 1. Katılımcıların Turizm Türlerine Göre Dağılımı

\begin{tabular}{lcrr}
\hline Turizm Türleri & Katılımcı Sayısı $(n)$ & Yüzde & Katılımcıların Yüzdesi \\
\hline Kültür Turizmi & 145 & 15,4 & $34,5 \%$ \\
\hline Termal Turizm & 67 & 7,1 & $16,0 \%$ \\
\hline Kış Turizmi & 72 & 7,7 & $17,1 \%$ \\
\hline Kongre Turizmi & 12 & 1,3 & $2,9 \%$ \\
\hline Yayla Turizmi & 64 & 6,8 & $15,2 \%$ \\
\hline Dağ ve Doğa Yürüyüşü & 273 & 29,1 & $65,0 \%$ \\
\hline Bisiklet Turizmi & 27 & 2,9 & $6,4 \%$ \\
\hline Kamp ve Karavan Turizmi & 185 & 19,7 & $44,0 \%$ \\
\hline Sportif Olta Balıkçı̆ı̆ı & 22 & 2,3 & $5,2 \%$ \\
\hline Kuş Gözlemciliği & 3 & 0,3 & $0,7 \%$ \\
\hline Atlı Doğa Yürüyüşü & 10 & 1,1 & $2,4 \%$ \\
\hline Bitki İnceleme & 14 & 1,5 & $3,3 \%$ \\
\hline Yamaç Paraşütü & 4 & 0,4 & $1,0 \%$ \\
\hline Yaban Hayatı Gözlemciliği & 41 & 4,4 & $9,8 \%$ \\
\hline Toplam & 939 & 100,0 & $223,6 \%$ \\
\hline
\end{tabular}

Ayrıca katılımcıların büyük çoğunluğu çalışan bireylerdir.

Turistlerin bir turistik alana gittiğinde tek bir turizm türüne değil, çeşitli aktiviteleri içeren birden fazla turizm türüne katılabileceği bilinmektedir. Bu nedenle araştırmaya katılan turistlerin anketi doldururken katılım sağladıkları turizm türlerinin tamamını işaretlemeleri istenmiştir. Araştırmaya katılan turistlerin katıldıkları turizm türlerine ilişkin sıklık tablosuna göre en fazla katılım sağlanan turizm türünün dağ ve doğa yürüyüşü (yüzde 29,1) olduğu belirlenmiştir. Bununla beraber kamp ve karavan turizmi (yüzde 19,7) ve kültür turizmine (yüzde 15,4) katılan turistlerin diğer turizm türlerine göre yoğunlukta olduğu da görülmektedir.

\section{Ölçme Modeli}

Ölçme modelinin değerlendirilmesi sürecinde faktör yükleri, açılanan ortalama varyans (AVE) ve bileşik güvenilirlik (CR) değerleri incelenmiştir. Birleşme geçerliliğini test edebilmek adına faktör yükleri, AVE ve CR değerleri incelenmiş- tir (Hair vd. 2017). Tablo 2 incelendiğinde incelenen faktör yüklerinin ve CR değerlerinin Hair ve diğerleri (2017) tarafından belirtilen değerler aralığında olduğu görülmektedir. Fornell ve Larcker'ın (1981) belirttiği üzere AVE değerlerinin $0,5^{\prime}$ in üzerinde olması gerekmektedir. $\mathrm{Bu}$ noktada Tablo 2'deki AVE değerleri incelendiğinde tüm değerlerin 0,5'in üzerinde olduğu görülmüştür. Bu bulgular incelendiğinde, çalışma verilerinin birleşme geçerliliği sağladığı görülmektedir.

Birleşme geçerliliği incelendikten sonra yapıların ayırt edici geçerliliği değerlendirebilmek için korelasyonların Heterotrait-Monotrait oranları (HTMT) incelenmiştir (Henseler vd. 2015). Ayırt edici geçerliliği test edebilmek adına çapraz yüklerin (cross-loading) ve Fornell ve Larcker kistasının incelenmesi geleneksel metotlar olarak görülmektedir. Bu nedenle, HTMT oranlarının incelenmesinin ayırt edici geçerliliği değerlendirebilmek adına yeterli olacağı belirtilmiştir (Henseler vd. 2015; Ali vd. 2018). Tablo 3 incelendiğinde, incelenen yapıların HTMT oranlarının belirtilen 
Tablo 1. Katılımcıların Turizm Türlerine Göre Dağılımı

\begin{tabular}{|c|c|c|c|c|c|}
\hline Faktörün Adı & $\begin{array}{c}\text { Faktör } \\
\text { Yükü }\end{array}$ & t-değeri & $\begin{array}{c}\text { (Güvenilirlik) } \\
\text { Cronbach's } \\
\text { Alpha }\end{array}$ & $A V E$ & $C R$ \\
\hline $\mathrm{Haz}$ & & & 0,751 & 0,567 & 0,838 \\
\hline Yeni bir deneyim yaşadığım için heyecanlıyım. & 0,687 & 11,348 & & & \\
\hline Aktivitelerden zevk aldım. & 0,730 & 12,208 & & & \\
\hline Bu turizm deneyiminden gerçekten keyif aldım. & 0,864 & 35,121 & & & \\
\hline Heyecan vericiydi. & 0,718 & 10,988 & & & \\
\hline Yenilik & & & 0,771 & 0,569 & 0,837 \\
\hline Hayatta bir kez yaşanabilecek bir deneyimdi & 0,719 & 10,884 & & & \\
\hline Eşsiz bir deneyimdi. & 0,910 & 33,027 & & & \\
\hline Önceki deneyimlerimden farklıydı. & 0,788 & 13,495 & & & \\
\hline Yeni bir şey deneyimledim. & 0,557 & 5,827 & & & \\
\hline Yerel Kültür & & & 0,844 & 0,762 & 0,906 \\
\hline Yerel halk hakkında güzel izlenimler edindim. & 0,887 & 34,369 & & & \\
\hline Yerel kültürü yakından deneyimledim. & 0,837 & 24,571 & & & \\
\hline Buradaki yerel halk oldukça dost canlısıydı. & 0,894 & 43,161 & & & \\
\hline Yenilenme & & & 0,832 & 0,665 & 0,887 \\
\hline Özgürleştirici bir deneyimdi. & 0,776 & 20,329 & & & \\
\hline Özgürlükten zevk aldım. & 0,696 & 12,804 & & & \\
\hline Yenileyici bir deneyimdi. & 0,895 & 47,049 & & & \\
\hline Yeniden canlandıran bir deneyimdi. & 0,878 & 38,691 & & & \\
\hline Anlamlılık & & & 0,772 & 0,686 & 0,868 \\
\hline Anlamlı bir şeyler yaptım. & 0,842 & 24,561 & & & \\
\hline Önemli bir şeyler yaptım. & 0,860 & 30,459 & & & \\
\hline Kendimle ilgili bir şeyler öğrendim. & 0,782 & 19,599 & & & \\
\hline Ilgilenim & & & 0,608 & 0,564 & 0,793 \\
\hline Gerçekten gitmek istediğim bir yeri ziyaret ettim. & 0,739 & 12,664 & & & \\
\hline $\begin{array}{l}\text { Gerçekleştirmek istediğim faaliyetlerden zevk } \\
\text { aldım. }\end{array}$ & 0,858 & 23,528 & & & \\
\hline Sunulan temel faaliyetlere karşı ilgiliydim. & 0,639 & 7,367 & & & \\
\hline
\end{tabular}


Tablo 1. Katılımciların Turizm Türlerine Göre Dağılımı (Devam)

\begin{tabular}{|c|c|c|c|c|c|}
\hline Bilgi & & & 0,781 & 0,697 & 0,873 \\
\hline Keşfedici bir deneyimdi. & 0,818 & 19,668 & & & \\
\hline Bilgilendirici bir deneyimdi. & 0,916 & 52,100 & & & \\
\hline Yeni kültürler deneyimledim. & 0,764 & 16,580 & & & \\
\hline Tekrar Ziyaret Etme Niyeti & & & 0,800 & 0,711 & 0,880 \\
\hline
\end{tabular}

Tablo 3. Ayırt Edici Geçerlilik Değerleri (HTMT Yöntemi)

\begin{tabular}{|c|c|c|c|c|c|c|c|c|}
\hline & $H a z$ & Yenilik & Yerel Kültür & Yenilenme & Anlamlılık & ilgilenim & Bilgi & Tekrar Ziyaret Etme Niyeti \\
\hline \multicolumn{9}{|l|}{$\mathrm{Haz}$} \\
\hline Yenilik & 0,433 & & & & & & & \\
\hline Yerel Kültür & 0,169 & 0,338 & & & & & & \\
\hline Yenilenme & 0,569 & 0,623 & 0,314 & & & & & \\
\hline Anlamlılık & 0,580 & 0,630 & 0,418 & 0,694 & & & & \\
\hline İlgilenim & 0,683 & 0,585 & 0,358 & 0,686 & 0,813 & & & \\
\hline Bilgi & 0,426 & 0,645 & 0,415 & 0,645 & 0,760 & 0,838 & & \\
\hline Tekrar Ziyaret Etme & 0,302 & 0,232 & 0,241 & 0,351 & 0,320 & 0,384 & 0,296 & \\
\hline
\end{tabular}

Tablo 4. Yapisal Model ve Hipotez Testleri

\begin{tabular}{llccc}
\hline & \multicolumn{1}{c}{ Hipotezler } & Tahmini Etki $(\beta)$ & t- değeri & Sonuç \\
\hline $\mathrm{H}_{1}:$ & Haz $\rightarrow$ Tekrar Ziyaret Etme Niyeti & 0,114 & 1,821 & Ret \\
\hline $\mathrm{H}_{2}:$ & Yenilik $\rightarrow$ Tekrar Ziyaret Etme Niyeti & 0,042 & 0,552 & Ret \\
\hline $\mathrm{H}_{3}:$ & Yerel Kültür $\rightarrow$ Tekrar Ziyaret Etme Niyeti & 0,125 & 2,572 & Kabul \\
\hline $\mathrm{H}_{4}:$ & Yenilenme $\rightarrow$ Tekrar Ziyaret Etme Niyeti & 0,134 & 2,095 & Kabul \\
\hline $\mathrm{H}_{5}:$ & Anlamllık $\rightarrow$ Tekrar Ziyaret Etme Niyeti & 0,013 & 0,209 & Ret \\
\hline $\mathrm{H}_{6}:$ & İlgilenim $\rightarrow$ Tekrar Ziyaret Etme Niyeti & 0,103 & 1,466 & Ret \\
\hline $\mathrm{H}_{7}:$ & Bilgi $\rightarrow$ Tekrar Ziyaret Etme Niyeti & 0,014 & 0,207 & \\
\hline
\end{tabular}

0,85 değerinin altında olduğu tespit edilmiştir (Henseler vd. 2015). Bu bulgular doğrultusunda çalışmanın ayırt edici geçerliliğin doğrulandığı görülmektedir.

\section{Yapısal Modelin Analizi}

Yapisal model sonucunda test edilen hipotezlerden iki tanesi kabul edilmiştir. Sonuçlar incelendiğinde yerel kültür boyutu ve tekrar ziyaret et- 
Onur Cüneyt Kahraman - Haluk Tanrıverdi

Tablo 5. Turizm Türleri ve Unutulmaz Turizm Deneyimi Farklılık Analizi

\begin{tabular}{|c|c|c|c|c|c|c|c|c|}
\hline \multirow[t]{4}{*}{ Değişkenler } & \multicolumn{8}{|c|}{ Turizm Türleri } \\
\hline & \multirow{2}{*}{\multicolumn{2}{|c|}{ Kültür Turizmi Termal Turizm }} & \multirow[b]{2}{*}{ Iş Turizmi } & \multirow[b]{2}{*}{ Yayla Turizmi } & \multirow{3}{*}{$\begin{array}{l}\text { Dağ ve Doğa } \\
\text { Yürüyüşü (E) }\end{array}$} & \multirow{3}{*}{$\begin{array}{c}\text { Kamp ve } \\
\text { Karavan } \\
\text { Turizmi (F) }\end{array}$} & \multirow{3}{*}{$\begin{array}{c}\text { Yaban Hayatı } \\
\text { (G) }\end{array}$} & \multirow{3}{*}{ Diğer $(H)$} \\
\hline & & & & & & & & \\
\hline & (A) & (B) & (C) & (D) & & & & \\
\hline $\mathrm{HZ}$ & 6,05 & 5,95 & 6,02 & 5,96 & 6,00 & 6,12 & 5,91 & 6,05 \\
\hline YN & 4,52 & 4,57 & 4,40 & 4,38 & 4,42 & 4,75 (E ve G) & 4,09 & 4,43 \\
\hline YK & $4,81$ ( $E$ ve $F)$ & $5,03$ (E ve $F)$ & 4,69 & 4,97 (E ve F) & 4,35 & 4,18 & 4,37 & 4,42 \\
\hline YNM & 5,65 & 5,76 & 5,70 & 5,69 & 5,70 & $5,97(A, E, G)$ & 5,52 & 5,70 \\
\hline ANL & 5,37 & 5,58 & 5,44 & 5,36 & 5,30 & 5,47 & 5,11 & 5,53 \\
\hline íg & 5,99 & 5,97 & 5,97 & 5,81 & 6,01 & 6,05 & 5,90 & 5,83 \\
\hline BLG & 5,26 & 5,40 & 5,38 & 5,26 & 5,28 & 5,39 & 5,13 & 5,51 \\
\hline
\end{tabular}

me niyeti arasında oluşturulan hipotez sonucuna göre yerel kültür boyutu tekrar ziyaret etme niyetini olumlu olarak anlamlı şekilde etkilemektedir $(\beta=0,125, p<0,01)$. Ayrica yenilenme boyutunun da tekrar ziyaret etme niyetini olumlu olarak etkilediği sonucuna ulaşılmıştır $(\beta=0,134, p<0,05)$. Haz, yenilik, anlamlılık, ilgilenim ve bilgi boyutlarının ise tekrar ziyaret etmeyi etkilemediği sonucuna ulaşılmıştır.

\section{Turizm Türleri ve Unutulmaz Turizm Deneyimi İlişkisine Yönelik Hipotez Testi}

Araştırma kapsamında incelenen kongre turizmi, bisiklet turizmi, sportif olta balıkçılı̆̆ı, kuş gözlemciliği, atlı doğa yürüyüşü, bitki inceleme, yamaç paraşütü gibi turizm türlerine katılımın az olması nedeniyle bu turizm türleri birleştirilmiş ve analize uygun hale getirilmiştir. Turizm türleri ile unutulmaz turizm deneyimi arasında bir fark olup olmadığını tespit edebilmek özel tablo üzerinde Bonferroni düzeltmesi analizi yapılmıştir.

Tablo 5'te görüldüğü üzere yenilik boyutu aç1sindan kamp ve karavan turizmine (Ort.=4,75) katılan turistlerin dağ ve doğa yürüyüşüne (Ort.= $4,42)$ ve yaban hayatı gözlemciliğine (Ort. $=4,09)$ katılan bireylere göre anlamlı bir farklılıklarının bulunduğu sonucuna ulaşılmıştır. Yerel kültür açısından yapılan analiz sonucunda kültür turizmine (Ort. $=4,81)$ katılan bireylerin dağ ve doğa yürüyüşüne (Ort.=4,81) ve kamp ve karan turizmine (Ort. $=4,81)$ katılan bireylere göre anlamlı bir farklılık içerdiği saptanmıştır. Termal turizme (Ort.= 5,03) katılan bireylerin dağ ve doğa yürüyüşüne (Ort. $=4,35)$ ve kamp ve karan turizmine $($ Ort. $=4,18)$ katılan bireylere göre anlamlı bir farklılık içerdiği bulunmuştur. Yayla turizmine (Ort.= 4,97) katılan bireylerin dağ ve doğa yürüyüşüne (Ort. $=4,35)$ ve kamp ve karan turizmine $($ Ort. $=4,18)$ katılan bireylere göre anlamlı bir farklılık içerdiği söylenebilir. Bununla beraber yenilenme boyutu açısından kamp ve karavan turizmine (Ort. $=5,97$ ) katılan bireylerin kültür turizmi (Ort.=5,65), dağ ve doğa yürüyüşü (Ort.= $5,70)$ ve yaban hayatı gözlemciliğine (Ort.=5,52) katılan turistlere göre anlamlı bir farklılığının olduğu görülmektedir. Yapılan analiz sonucunda H8 kabul edilmiştir.

\section{SONUÇ VE ÖNERILER}

$\mathrm{Bu}$ araştırma, turistlerin tekrar ziyaret etme niyetini etkileyen unutulmaz turizm deneyimi boyutlarını inceleyebilmek amacıyla gerçekleştirilmiştir. Bununla birlikte, turistlerin yaşadıkları dene- 
yimlerin turizm türlerine göre farklılık gösterip göstermediği incelenmiştir. Bu kapsamda Bolu iline gelen yerli turistlerden toplanan veriler analiz edilmiştir. Elde edilen sonuçlar alanyazın ile karşılaştırılmış ve araştırma sonuçları doğrultusunda önerilerde bulunulmuştur.

Unutulmaz turizm deneyiminin tekrar ziyaret etme niyetine olan etkisi ile ilgili olarak yapılmış birçok çalışma bulunmaktadır (Yoon ve Uysal 2005; Kim vd. 2010; Kim ve Ritchie 2014; Chen ve Rahman 2018; Gohary vd. 2018; Kim 2018). Yapılan bu çalışmada unutulmaz turizm deneyimi boyutları arasında yer alan haz, yenilik, yerel kültür, yenilenme, anlamlılık, ilgilenim ve bilgi boyutlarının tekrar ziyaret etme niyeti üzerinde bir etkisini olup olmadığı araştırılmıştır. Alan yazında bulunan çalışmalar incelendiğinde haz boyutunun tekrar ziyaret etme niyetini olumlu olarak etkilediğine ilişkin çalışmalar bulunsa da bu çalışmada anlamlı bir sonuç elde edilmemiştir. Bununla birlikte, yerel kültür deneyiminin tekrar ziyaret etme niyetini etkilediği sonucu diğer çalışmalara göre farklılık göstermektedir (Kim vd. 2010; Gohary 2020). Ayrica, yenilenme deneyiminin Kim ve Ritchie (2014) ve Gohary vd. (2020) yaptıkları çalışmaya benzer olarak tekrar ziyaret etme niyetini olumlu etkilediği sonucuna ulaşılmıştır. Diğer çalışmaların sonuçlarından farklı olarak bu araştırma kapsamında incelenen yenilik, anlamlılık ve bilgi boyutunun tekrar ziyaret etme niyeti üzerinde bir etkisinin bulunmadı $\breve{g}_{1}$ sonucuna varılmıştır (Kim ve Ritchie 2014; Gohary vd. 2020). Araştırma kapsamında incelenen unutulmaz deneyim boyutlarının turizm türlerine göre farklılıklar gösterdiğine ilişkin hipotezin de daha önceden yapılan çalışmalarla doğru orantılı sonuçlar verdiği görülmektedir (Petrick 2002; Tran ve Ralston 2006; Walls vd. 2011). Bu açıdan kültür turizmi, kamp ve karavan turizmi, termal turizm ve yayla turizmine katılan bireylerin yerel kültür, yenilik ve yenilenme bakımından diğer turizm türlerine oranla farklılıklar içerdiği söylenebilir.

Özellikle ürün odaklı pazarlamaya önem verilmesi ve turistlerin istek ve ihtiyaçları göz önünde bulundurulması, unutulmaz bir turizm deneyimini oluşturması açısından birtakım olum- suzluklar oluşturmaktadır (Zhang vd. 2018). Bu noktada araştırma sonucunda elde edilen bilgiler doğrultusunda, turistlerin tekrar ziyaretini sağlayabilmek adına unutulmaz turizm deneyimi unsurlarının dikkate alınması oldukça önemlidir. Ortaya çıkan sonuçlar çerçevesinde turistik alan yönetimine ve turizm işletmecilerine yönelik olarak birtakım öneriler sunulmuştur. Destinasyon yönetimleri ve turistik işletmelerin unutulmaz bir deneyim oluşturabilmesi için öncelikli olarak turistlerin yerel kültür ve yenilenme deneyimi hissedebilecekleri ürünler oluşturmaları gerekmektedir. Bununla beraber yerel kültür ve yenilenme ihtiyacını karşılayan turistlerde tekrar ziyaret etme niyetinin oluştuğu görülmektedir. Bolu ili açısından düşünüldüğünde, kamp ve karavan turizmi, termal turizm, yayla turizmi ve kültür turizminin yerel kültür, yenilik ve yenilenme açısından diğer turizm türlerine oranla farklılıklar içerdiği bu nedenle bu turizm türlerine yönelik olarak pazarlama ve tutundurma çalışmalarının artırılması turistik alana katkı sunacaktır. Bununla beraber bu turizm türlerine katılım gösteren kişilere bölge hakkında ve bu bölgedeki yerel kültür ile alakalı olarak broşürler hazırlanıp, tanıtım faaliyetleri yürütülebilir. Yenilenme ihtiyaçlarını gidermek isteyen bireylerin sakin ve huzurlu bir tatil geçirme isteği bulunmasından ötürü Bolu ilinin sahip olduğu özellikler bakımından önemli bir turistik bölge olduğu ve buraya yönelik olarak büyük illerden gelebilecek turistlere çeşitli turlar düzenlenebileceği söylenebilir. Bu araştırmanın sonucu sadece turizm işletmeleri ve turistik alan yönetimleri açısından değil gelen turistler açısından da sşık tutmaktadır. Bu açıdan gelen turistlerin kendilerini tanıyarak unutulmaz bir deneyim yaşamaları oldukça önemlidir.

Gelecekte yapılacak çalışmalar açısından incelenen değişkenlere aracılık yapabilecek olan memnuniyet düzeyi, turistik alanın imajı, tutum ve davranışsal değerler eklenerek farklı çalışmalar gerçekleştirilebilir. Bununla beraber unutulmaz turizm deneyimini ölçebilmek için farklı boyutlar eklenebilir. Özellikle Bolu'nun mutfak kültürüne ilişkin deneyimler ölçülebilir. Bu çalışmanın sınırlılıklarına bakıldığında sadece Bolu ilinde turizm faaliyetlerine bireysel olarak kat1- 
lan yerli turistleri içermektedir. Ayrıca, araştırmanın amacı incelenen turizm türleri hakkında bilgi sunmaktadır. Son olarak, veriler kolayda örneklem yöntemiyle toplanması ayrı bir sınırlılığı oluşturmaktadır.

\section{KAYNAKÇA}

Aho, S. K. (2001). Towards A General Theory of Touristic Experiences: Modelling Experience Process in Tourism, Tourism Review, 56 (3/4): 33-37.

Ali, F., Kim, W. G., Li, J. ve Jeon, H. M. (2018). Make It Delightful: Customers' Experience, Satisfaction and Loyalty in Malaysian Theme Parks, Journal of Destination Marketing and Management, 7: 1-11.

Arslaner, E. ve Erol, G. (2017). Alternatif Turizmin Bazı Türleri Üzerine Bir Değerlendirme, Journal of Tourism and Gastronomy Studies, 5 (4): 422-438.

Bujisic, M., Bilgihan, A. ve Smith, S. (2015). Relationship between Guest Experience, Personality Characteristics, and Satisfaction: Moderating Effect of Extraversion and Openness to Experience, Tourism Analysis, 20 (1): 25-38.

Çetin, G. ve Bilgihan, A. (2016). Components of Cultural Tourists' Experiences in Destinations, Current Issues in Tourism, 19 (2): 137-154.

Chandralal, L. ve Valenzuela, F. R. (2013). Exploring Memorable Tourism Experiences: Antecedents and Behavioural Outcomes, Journal of Economics, Business and Management, 1 (2): 177-181.

Chen, H. ve Rahman, I. (2018). Cultural Tourism: An Analysis of Engagement, Cultural Contact, Memorable Tourism Experience and Destination Loyalty, Tourism Management Perspectives, 26: 153-163.

Cohen, E. (1972). Toward A Sociology of International Tourism, Social Research, 39 (1): 164-182.

Do Valle, P. O. ve Assaker, G. (2016). Using Partial Least Squares Structural Equation Modeling in Tourism Research: A Review of Past Research and Recommendations for Future Applications, Journal of Travel Research, 55 (6): 695-708.

Fornell, C. ve Larcker, D. F. (1981). Evaluating Structural Equation Models with Unobservable Variables and Measurement Error, Journal of Marketing Research, 18 (1): 3950.

Forza, C. ve Filippini, R. (1998). TQM Impact on Quality Conformance and Customer Satisfaction: A Causal Model, International Journal of Production Economics, 55 (1): 1-20.

Gohary, A., Pourazizi, L., Madani, F. ve Chan, E. Y. (2020). Examining Iranian Tourists' Memorable Experiences on Destination Satisfaction and Behavioral Intentions, Current Issues in Tourism, 23 (2): 131-136.

Hair, Jr, J. F., Hult, G. T. M., Ringle, C. ve Sarstedt, M. (2017). A Primer on Partial Least Squares Structural Equation Modeling (PLS-SEEM) (İkinci baskı). California: Sage Yayınları.

Hair, J. F., Black, W. C., Babin, B. J. ve Anderson, R. E. (2014). Multivariate Data Analysis: Pearson New International Edition. Londra: Pearson Education Limited.
Hayes, D. ve MacLeod, N. (2007). Packaging Places: Designing Heritage Trails Using an Experience Economy Perspective to Maximize Visitor Engagement, Journal of Vacation Marketing, 13 (1): 45-58.

Henseler, J., Ringle, C. M. ve Sarstedt, M. (2015). A New Criterion for Assessing Discriminant Validity in VarianceBased Structural Equation Modeling, Journal of The Academy of Marketing Science, 43 (1): 115-135.

Kim, J. H. (2010). Determining the Factors Affecting the Memorable Nature of Travel Experiences, Journal of Travel and Tourism Marketing, 27 (8): 780-796.

Kim, J. H. (2014). The Antecedents of Memorable Tourism Experiences: The Development of a Scale to Measure the Destination Attributes Associated with Memorable Experiences, Tourism Management, 44: 34-45.

Kim, J. H. ve Ritchie, J. B. (2014). Cross-Cultural Validation of a Memorable Tourism Experience Scale (MTES), Journal of Travel Research, 53 (3): 323-335.

Kim, J. H., Ritchie, J. B. ve McCormick, B. (2012). Development of A Scale to Measure Memorable Tourism Experiences, Journal of Travel Research, 51 (1): 12-25.

Kim, J. H., Ritchie, J. R. ve Tung, V. W. S. (2010). The Effect of Memorable Experience on Behavioral Intentions in Tourism: A Structural Equation Modeling Approach, Tourism Analysis, 15 (6): 637-648.

Kültür ve Turizm Bakanlığ1 (2020). Turizm İstatistikleri, https://yigm.ktb.gov.tr/TR-9851/turizm-istatistikleri.html, Erişim tarihi: 28 Temmuz 2020.

Mossberg, L. (2007). A Marketing Approach to The Tourist Experience, Scandinavian Journal of Hospitality and Tourism, 7 (1): 59-74.

Oh, H. Fiore, A. M. ve Jeoung, M. (2007). Measuring Experience Economy Concepts: Tourism Applications, Journal of Travel Research, 46 (2): 119-132.

Otto, J. E. ve Ritchie, J. B. (1996). The Service Experience in Tourism, Tourism Management, 17 (3): 165-174.

Özcan, E. (2005). Bolu İlinde Turizmi Etkileyen Faktörler ile Doğal, Tarihi ve Kültürel Turizm Değerleri, Gazi Üniversitesi Gazi Eğitim Fakültesi Dergisi, 25 (1): 55-75.

Petrick, J. F. (2002). An Examination of Golf Vacationers' Novelty, Annals of Tourism Research, 29 (2): 384-400.

Pine, B. J. ve Gilmore, J. (1999). The Experience Economy: Work Is Theatre and Every Business A Stage. Boston: Harvard Business School Press.

Quan, S. ve Wang, N. (2004). Towards A Structural Model of The Tourist Experience: An Illustration from Food Experiences in Tourism, Tourism Management, 25 (3): 297305

Sato, S., Kim, H., Buning, R. J. ve Harada, M. (2018). Adventure Tourism Motivation and Destination Loyalty: A Comparison of Decision and Non-Decision Makers, Journal of Destination Marketing and Management, 8: 74-81.

Tran, X. ve Ralston, L. (2006). Tourist Preferences Influence of Unconscious Needs, Annals of Tourism Research, 33 (2): 424-441.

Tung, V. W. S. ve Ritchie, J. B. (2011). Exploring the Essence of Memorable Tourism Experiences, Annals of Tourism Research, 38 (4): 1367-1386. 
Usakli, A. ve Kucukergin, K. G. (2018). Using Partial Least Squares Structural Equation Modeling in Hospitality and Tourism, International Journal of Contemporary Hospitality Management, 30 (11): 3462-3512.

Walls, A. R., Okumus, F., Wang, Y. R. ve Kwun, D. J. W. (2011). An Epistemological View of Consumer Experiences, International Journal of Hospitality Management, 30 (1): $10-21$.

Yoon, Y. ve Uysal, M. (2005). An Examination of The Effects of Motivation and Satisfaction on Destination Loyalty: A Structural Model, Tourism Management, 26 (1): 45-56.

Yosmanoğlu, N. ve Engin, F. (2003). Bolu İli Gelişme Planı: Hizmet Sektörü, Bolu: T.C. Başbakanlık Devlet Plan- lama Teşkilatı Müsteşarlığı ve T.C. Bolu Valiliği, Bolu Belediyesi, Bolu Ticaret ve Sanayi Odası, http://www. bolu.gov.tr/ortak_icerik/bolu/bilgi-islem/gerekli-dosyalar/ xfiles-2_hizmetler_sektoru.pdf, Erişim Tarihi: 20 Aralık 2020.

Zhang, H., Wu, Y. ve Buhalis, D. (2018). A Model of Perceived Image, Memorable Tourism Experiences and Revisit Intention, Journal of Destination Marketing and Management, 8: 326-336.

Zhang, J., Cai, L. A. ve Kavanaugh, R. R. (2008). Dimensions in Building Brand Experience for Economy Hotels-A Case of Emerging Market, Journal of China Tourism Research, 4 (1): 61-77.
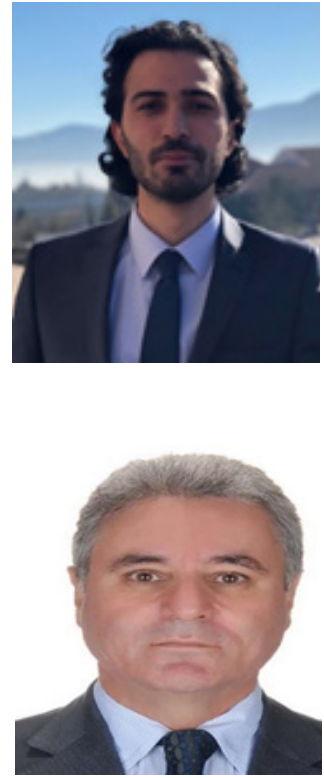

\section{Onur Cüneyt KAHRAMAN}

İstanbul Arel Üniversitesi Uygulamalı Bilimler Yüksekokulu Turizm ve Otel İ̧̧letmeciliği Bölümü’nden mezun oldu (2013). Yüksek lisans derecesini İstanbul Üniversitesi'nden Turizm İşletmeciliği Dalı'ndan (2015), doktora derecesini de İstanbul Üniversitesi'nden Turizm Işletmeciliği Dalı'ndan aldı (2019). Bolu Abant İzzet Baysal Üniversitesi'nde çalışmaya başladı (2015). İstanbul Üniversitesinde Araştırma Görevlisi olarak çalıştı (2015-2018). Halen Bolu Abant İzzet Baysal Üniversitesi Turizm Fakültesi'nde görev yapmaktadır. Temel çalışma alanları turist deneyimi, sürdürülebilir turizm ve turizm işletmeciliğidir.

\section{Haluk TANRIVERDi}

İstanbul Üniversitesi, Orman Fakültesi, Tütün Eksperleri Yüksekokulu, Tütün teknolojisi Mühendisliği Bölümü’nden mezun oldu (1985). Yüksek lisans derecesini İstanbul Üniversitesi'nden Organizasyon ve İşletme Politikası Dalı'ndan (1987), doktora derecesini de İstanbul Üniversitesi'nden Organizasyon ve İşletme Politikası Dalı́ndan aldı (1990). İstanbul Üniversitesi'nde araştırma görevlisi olarak çalışmaya başladı (1986-1993), Öğretim üyesi unvanıyla sırasıyla, Manisa Celal Bayar Üniversitesi'nde (19931994), Çanakkale Onsekiz Mart Üniversitesi'nde (1994-1996), Sakarya Üniversitesi'nde (1996-2012) ve Karabük Üniversitesi'nde (2012-2013) görev aldı. Üniversite dışında Gümrük ve Tekel Bakanlığı Tekel İşletmeleri Genel Müdürlüğü’nde (1981-1986) görev yaptı. Doçentlik unvanını Yönetim ve Strateji alanından aldı (2013). Profesörlüğe İstanbul Üniversitesi'nde yükseltildi (2017). Halen İstanbul Üniversitesi İktisat Fakültesi, Turizm İşletmeciliği bölümünde görev yapmaktadır. Temel çalışma alanları yönetim ve organizasyon, insan kaynakları yönetimi, örgütsel davranış ve stratejik yönetimdir. 